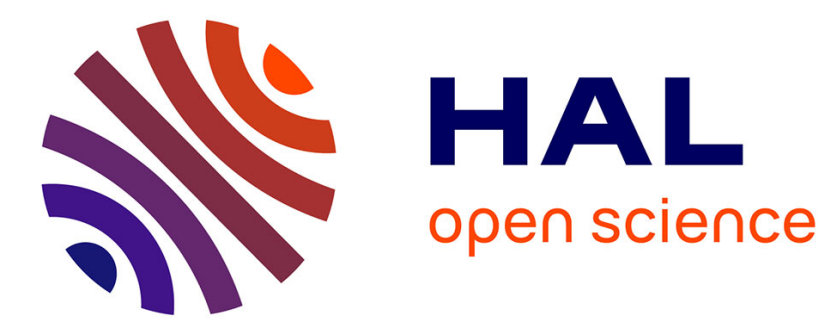

\title{
Early Computer Development in Poland
}

Marek Holyński

\section{To cite this version:}

Marek Holyński. Early Computer Development in Poland. IFIP International Conference on the History of Computing (HC), Sep 2018, Poznan, Poland. pp.71-86, 10.1007/978-3-030-29160-0_4 . hal-02386551

\section{HAL Id: hal-02386551 \\ https://hal.inria.fr/hal-02386551}

Submitted on 29 Nov 2019

HAL is a multi-disciplinary open access archive for the deposit and dissemination of scientific research documents, whether they are published or not. The documents may come from teaching and research institutions in France or abroad, or from public or private research centers.
L'archive ouverte pluridisciplinaire HAL, est destinée au dépôt et à la diffusion de documents scientifiques de niveau recherche, publiés ou non, émanant des établissements d'enseignement et de recherche français ou étrangers, des laboratoires publics ou privés. 


\title{
Early Computer Development in Poland
}

\author{
Marek Hołyński \\ Polish Information Processing Society, ul. Solec 38 lok. 103, 00-394 Warszawa, Poland \\ marek.holynski@gmail.com
}

\begin{abstract}
The paper describes the history of early computing in Poland from the establishment of the Mathematical Apparatuses Group in 1948, which later changed into the independent Mathematical Apparatuses Division of the Polish Academy of Sciences and then finally became the Institute of Mathematical Machines, where the ZAM computers were designed and produced. Two other research and development centers, which were most important in the late 1950s and 1960s are also described: the Faculty of Telecommunications of the Warsaw Institute of Technology (UMC machines) and Elwro (Odra series). When the production of RYAD computers started in 1973, the production of these machines had to be dropped.
\end{abstract}

Keywords: History of computing, Polish computing.

\section{$1 \quad$ Introduction}

The early development of computers in Poland has been very sparsely documented in English-language publications. English-language articles published in professional periodicals during that period usually detailed specific technical solutions, and seldom gave sufficient historical context. PIPS - the Polish Information Processing Society (Polskie Towarzystwo Informatyczne - PTI) has been trying to collect all of these articles, but currently only has two of them in its archives [1,2], which might be partially considered historical studies. Both concentrate primarily on the personal achievements of the authors and dedicate less detail to other works carried out in parallel. Moreover, these works focus on the 1940s and ' $50 \mathrm{~s}$, and do not take into account the consequences of these developments in the following decades.

The Polish-language resources are richer [3-14], but even they do not provide a full picture. Some, which are not referenced here, were simply juxtapositions of dates and milestones. Others were limited to very specific computer applications in particular sectors of the economy or overly personalized memories. Often times, attempts at a more comprehensive summary of the subject contradicted prior work or were continuations of long-outdated controversial discussions.

As the anniversary of the 70th birthday of Polish informatics drew near, PIPS was tasked with the coordination of jubilee ventures prepared by various government institutions, universities, associations and companies. We had to organize our historical knowledge to fill existing gaps and develop a comprehensive description of the history of Polish computing. Not only because this story needs to be better known, but also to 
serve as a reference during the number of presentations for this event. Moreover, such an overview should not be reduced to a dry litany of technical parameters, people, and inventions. Instead, it should serve as a historical narrative that is interesting even to the ordinary reader or listener. This task was originally assigned to me as chairman of the national commemoration committee.

The preliminary material describing the years 1949-73 consisted of 65 pages. Several corrections were made after consultation with the PIPS's historical section and a number of discussions with the Society board of directors. It was then printed in sections to consecutive PIPS's bulletins [15-20], which are regularly distributed in paper and electronically to all members. Their comments and additions have also been taken into account. The following article is a significantly compressed English version of that text.

The initial part of this paper draws partially from two previously cited articles and the missing data is supplemented by information about other parallel achievements. The data presented has been correlated with facts established in the course of my work at the Institute of Mathematical Machines (IMM) from 1970-81. It was then the country's leading R\&D institution in this field, and still employed most of the pioneers from early days of Polish computer science. These pioneers were very happy to share their memories of the 1950s and 1960s, and I was equally happy to write them down.

Two other important resources for historical information used in this paper should also be mentioned. In 2008, I became the IMM director, which gave me direct access to the institution's rich archives. In the same year, I was elected as president of the Polish Information Processing Society. Shortly after, we established a historical section in PIPS, which was officially authorized to access collections of state archives. Thus, we began to gather, organize and digitize all available documents and private relations. Most of the material referring to the 1960s and early 1970s comes from these two sources.

\section{Mathematical Apparatuses Group}

On December 23, 1948, the weather in Warsaw was particularly bad. Wet snow continued to fall as the inhabitants of the ruined city desperately tried to salvage what they could of their holidays with a meager meal for their family. Only a small group of people seemed untroubled by the worries of the upcoming celebrations. These were attendees of a seminar on electronic calculating machines, listening to a talk given by Kazimierz Kuratowski.

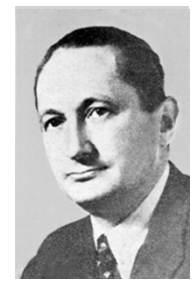

Fig. 1. Kazimierz Kuratowski. Source: Polish Wikipedia 
Kuratowski was a renowned topologist and director of the Institute of Mathematics in the Polish Academy of Sciences. He had just returned from a series of lectures in the United States, where he was shown ENIAC, the first electronic general-purpose computer, dubbed in the press as "the giant brain." His excitement about the newly built machine sparked great motivation among the listeners and led them to the immediately form a new research team.

The team, officially named the Mathematical Apparatuses Group, began building their own computer, despite having access to very limited resources. The researchers, who wore leaky boots and were barely surviving on the food parcels from post-WWII international relief agencies, did not have access to the proper equipment, parts, or even premises to pursue their endeavors. Moreover, the new American advancements in relevant fields were not often shared with the public, much less other countries, due to their applications in the military. Even the technical details which were released did not often reach Poland, as a result of the Iron Curtain.

The Mathematical Apparatuses Group was provided three rooms at the Institute and for quite a while their work remained only on paper. Their first attempts to deal with real devices did not bring significant results. For each damaged module they repaired, another one broke down, and the process would repeat.

\section{$3 \quad$ Analog or Digital?}

Finally, in 1953, they were able to get something working: an analog machine built with vacuum tubes, which was called the Differential Equations Analyzer (ARR). It was able to solve complex differential equations with very high accuracy and was used for a number of practical applications, including the design of turbines and aircrafts.

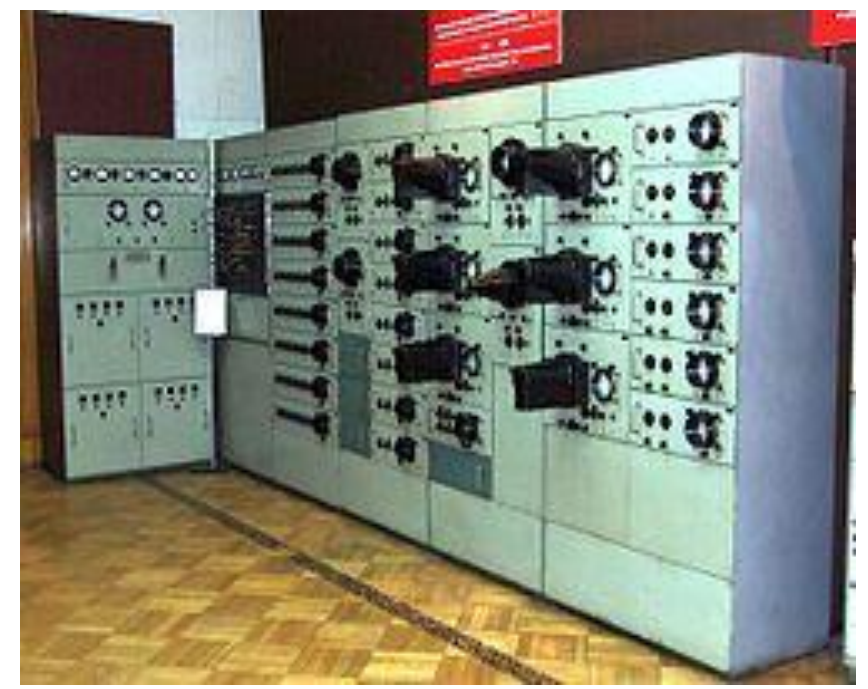

Fig. 2. Differential Equations Analyzer. Source: Archives of the Institute of Mathematical Machines with permission of the Institute's director. 
The next machine, the Algebraic Linear Equations Analyzer (ARAL), also proved to be useful. In subsequent versions, ARAL-1, -2 and -3 served to solve systems of equations (in fact, not only linear). Both ARR and ARAL were analog machines designed exclusively for a single task and nothing more. At the time, they seemed like the obvious choice because of the team's considerable experience in analog construction and the low efficiency of vacuum tubes. However, the advent of digital devices had brought about much more versatile machines that could be programmed for various types of calculations and were less susceptible to accumulating errors.

The first attempt to construct a digital machine was made in the years 1953-1955 by the team led by Romuald Marczyński. The Electronic Machine for Automatic Calculations (EMAL) was said to perform 2000 additions or subtractions, 450 multiplications, and 230 divisions per second. The solution which allowed for the "fast" memory of this machine consisted of a number of glass tubes filled with mercury, which could often not be sealed adequately, resulting in a health hazard.

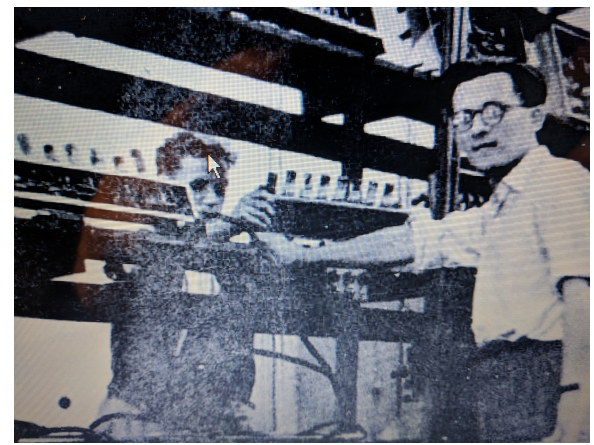

Fig. 3. Romuald Marczyński (in a white shirt) while working on the Electronic Machine for Automatic Calculations (EMAL) [2].

According to an anecdote passed from one generation of computer scientists to the next, one of the team members was reminded of a commonly used item made of latex that had the perfect dimensions for sealing the glass tubes. While the saleswomen at the pharmacy were not particularly surprised when he requested one hundred pieces, they were taken aback by the request to invoice these highly personal items to the Polish Academy of Sciences.

Unfortunately, this machine was never fully launched - it was too unreliable. The components available at that time in Poland (lamps, connectors, etc.) were of low quality and caused problems too difficult to overcome. It took significant labor to build individual machine modules, which would cease to function in only two or three days. Repairs were often highly complex and seemingly indefinite, constantly requiring new components.

Newspapers at the time which mentioned these projects usually focused on intellectual challenges and conceptual difficulties in creating an "electronic brain," but seldom focused on the real problems with which the researchers were struggling. How could they make a tangle of cables and electronic components (some of which were remains 
from the German army during occupation) function properly for a reasonable amount of time? Statistics from these years show that, for these devices, downtime for failures and maintenance significantly exceeded the time of effective operation.

\section{From ABC to XYZ}

In order to consolidate the existing research and design efforts, the Polish Academy of Sciences established the independent Mathematical Apparatuses Division (Zakład Aparatów Matematycznych - ZAM) in 1957. It was there that in the autumn of 1958, the first Polish electronic digital machine was launched with the name XYZ.

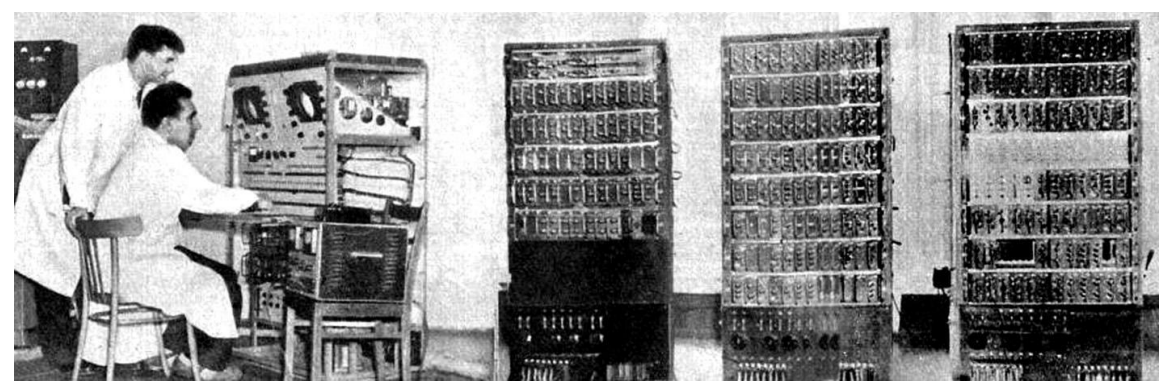

Fig. 4. XYZ digital computer. Source: Archives of the Institute of Mathematical Machines with permission of the Institute's director.

It used 400 tubes and 2000 diodes, flip-flops on one triode, had drum memory and punched cards for input and output. It could perform up to 1000 arithmetic operations per second and had an internal binary language with symbolic addressing.

The head of the team, prof. Leon Łukaszewicz, when asked by journalists why the machine was named XYZ, would answer: "Well, the version we started with was called $\mathrm{ABC}$, and then there were others." Łukaszewicz was also the representative of the Polish Academy of Sciences to IFIP from 1961 to 1985 and Vice President of IFIP from 1964 to 1968.

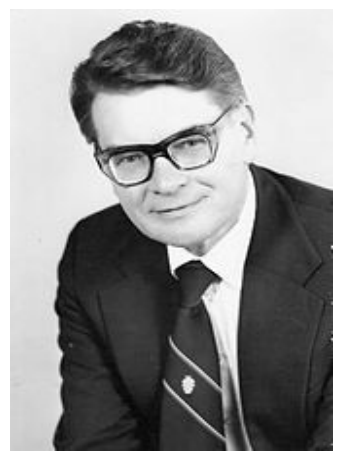

Fig. 5. Leon Łukaszewicz 
XYZ became a real milestone in the development of Polish computers. The presentations to government officials and the general public aroused great interest and attention was drawn to the possibility of wide-spread production and application.

At that time, commercial applications for such an efficient machine had only just begun to emerge. In 1960 the first improved version of XYZ, called ZAM-2, was built. It included 600 kilobits of memory, teletype and a paper tape reader, and was suitable for mass production. The software, especially System of Automatic Coding SAKO (often dubbed a Polish Fortran), was one of the major selling points of this machine. For the next three years a series of twelve units were produced, a number which was quite significant for the time.

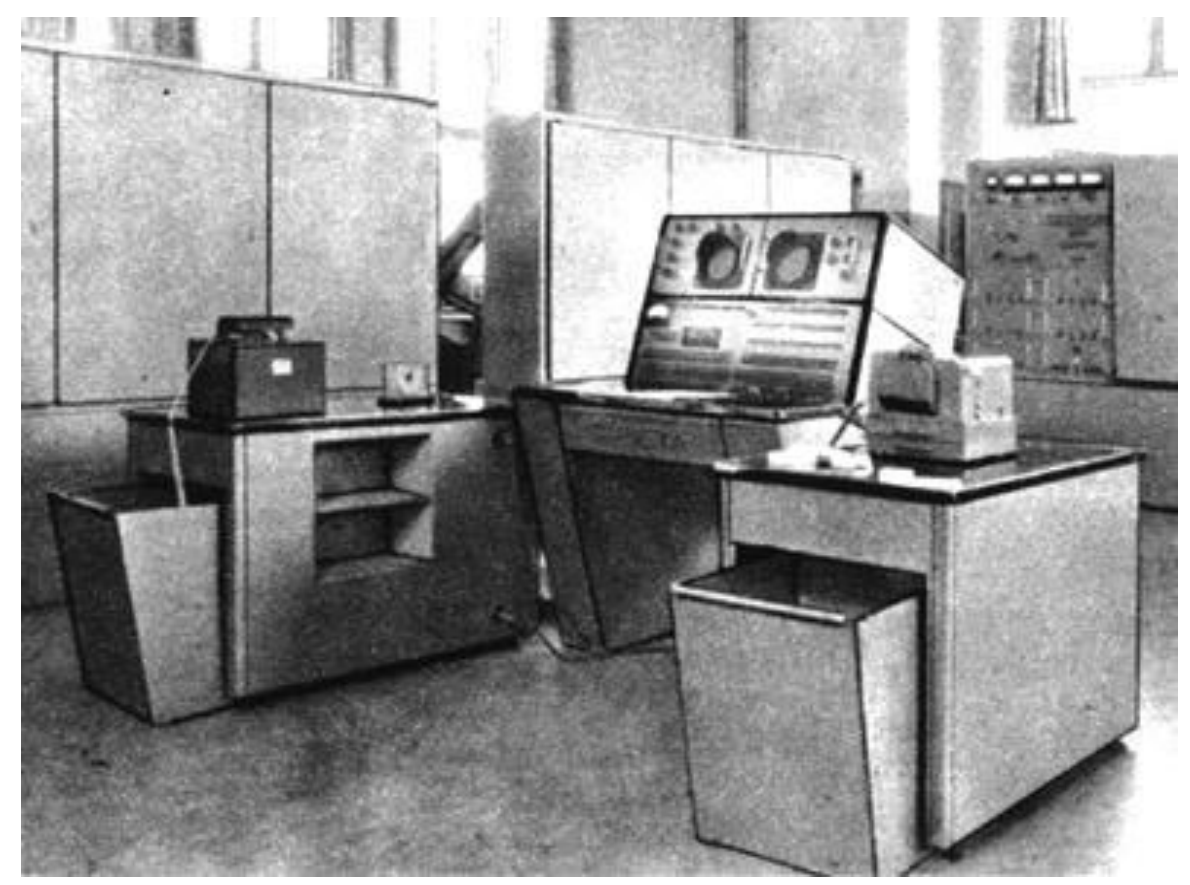

Fig. 6. ZAM-2. Source: Archives of the Institute of Mathematical Machines with permission of the Institute's director.

ZAM-2 was successfully used in various institutions for numerical calculations and data processing both at home and abroad, as evidenced by the email (quoted here literally) sent by a German user in March 2017, requesting permission to use pictures of the ZAM-2 on his personal website:

Dear Mr. Direktor,

More than 50 years ago the ironworks in village Hennigsdorf have acquired a computer ZAM 2 GAMMA of the IMM. 10 years I was responsible for the servicing of the machine. With pleasure I would publish this event on my homepage. In the draught the pictures which come from the education in the IMM are included. If it was right to them, that I the draught sends as a ZIP file to receive her approval for the publication. 
Permission, of course, was granted. Clearly, the machine had some fans.

The Mathematical Apparatuses Division, which by 1962 was operating out of its own building, began its transformation into the Institute of Mathematical Machines (Instytut Maszyn Matematycznych - IMM), as mentioned in the above email. In order to maintain the tradition, the Institute has existed for years under the old name, despite the burden of facing continuous inquiries (especially from younger generations) about what mathematical machines really are.

The word "computer" was only allowed to appear in the Polish language fairly late - in the mid-1970s. Before, it was routinely replaced by the censors' office with the phrase "electronic calculating machine," a compulsory copy of the Russian term for computers.

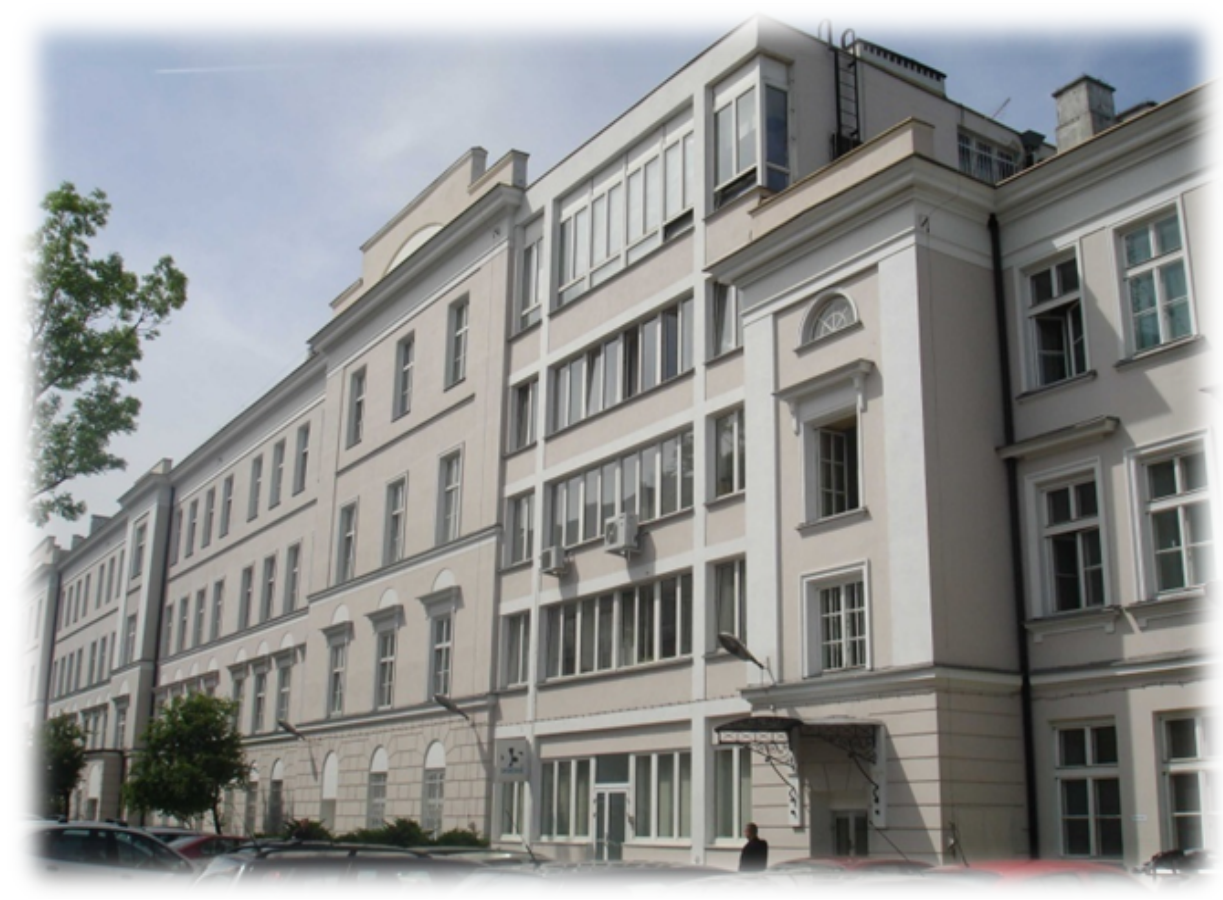

Fig. 7. Instytut Maszyn Matematycznych. Source: Archives of the Institute of Mathematical Machines with permission of the Institute's director.

\section{We Need More Computers}

XYZ proved that building such devices was possible in Poland, so other research centers began to find interest in computers. The Warsaw Institute of Technology (WIT) already had some experience with machines dedicated to specialized mathematical calculations. The system PARK [8] developed there in 1956 was already a digital device, albeit built on relays instead of tubes. It had been used to solve combinations of algebraic equations for over fifteen years. 
Shortly after, an impressive set of projects was launched at the Faculty of Telecommunications headed by Antoni Kiliński, later the president of WIT. Incidentally, Kiliński and Marczyński are the only Poles among about one hundred people honored with the IEEE Computer Society Pioneer Award, crediting scientists for their contributions in the creation of computers.

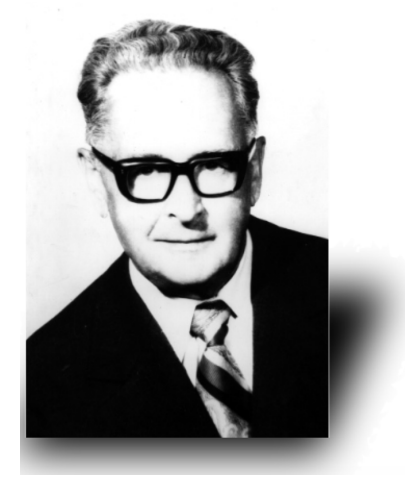

Fig. 8. Antoni Kiliński. Source: Polish Wikipedia

The part of WIT's strategy of was to create computers dedicated for special tasks. The AMC (Administrative Digital Machine) was to be used for data processing; the GEO had a multiprocessor operating system, Fortran translator, several versions of assembler and geodetic programs sets, and revolutionized land measurements in Poland; the ANOPS series was designed to support biomedical research [9], and many of the 150 machines produced worked in medical centers around the world. In fact, the ANOPS was the first Polish computer ordered by the leading American and Canadian research institutions. 


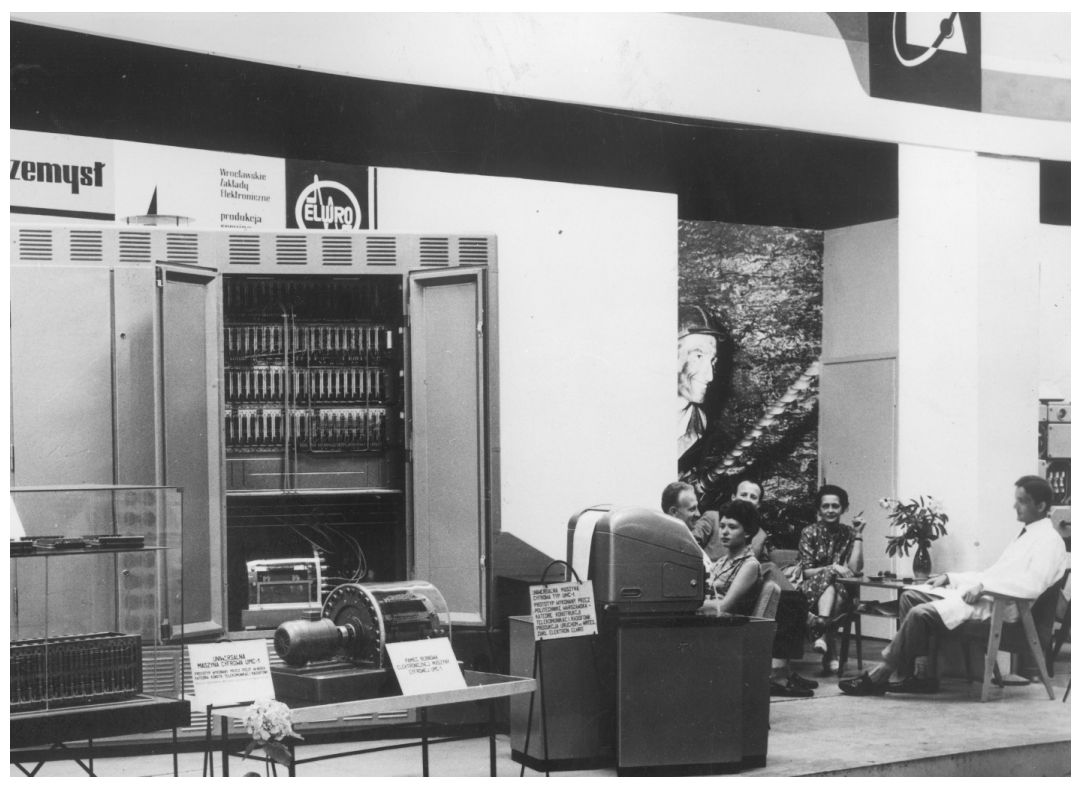

Fig. 9. UMC-1 at the exhibition in Moscow; drum memory was exposed in the foreground. Source: Polish Wikipedia

The most well-known of the computers created at the Warsaw University of Technology was undoubtedly the UMC series (Universal Digital Machine). The UMC-1 prototype was developed in 1960. It was a machine capable of performing 100 operations per second, equipped with a drum memory capacity of 144 kilobits. The construction was so successful that it was chosen for large-scale serial manufacturing. Its blueprints and documentation was handed to Elwro factory, where industrial production began the next year. By 1964, 25 of these machines were made. UMC-1 was a vacuum tube machine, but later versions, such as the UMC-10 (which replaced it in 1965) used transistors and magnetic-core memory.

The third major research center was the Nuclear Research Institute of the Polish Academy of Sciences. A computational group was organized there for supporting the design of nuclear reactors, later transformed into the Department of Applied Mathematics. In 1956, development of the EMAL machine was moved there and shortly after, the machine was put to use. Known as the EMAL-2, it was used for a number of years and then transferred to the Computational Center of the Polish Academy of Sciences.

\section{ELWRO}

The Elwro factory, established in 1959 in the city of Wrocław, was to be the production base of the national electronics industry. However, according to everyone who remembers those times, the real intention from the very beginning was to create a factory producing computers $[10,11]$. 


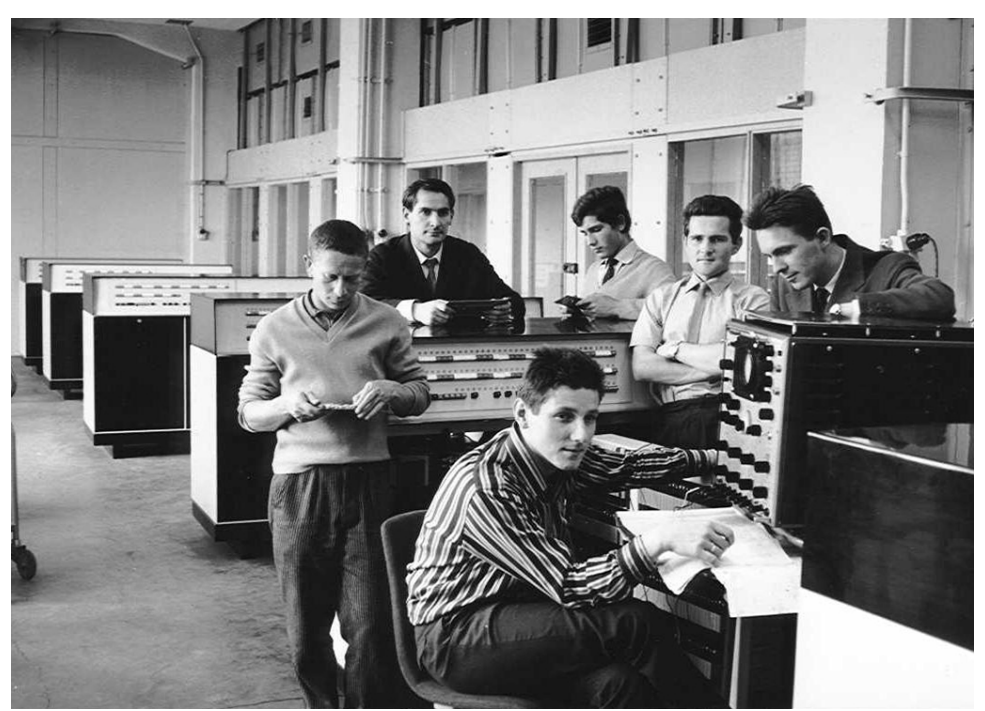

Fig. 10. Launching Odra 1003. Source: Memoirs of Mr. Wojciech Lipko (https://polskiekomputery.pl/mgr-inz-wojciech-lipko-wspomnienia, last accessed 2018/11/02), who is visible in the foreground in a striped shirt.

In addition to producing UMC machines, Elwro also had its own plans. A development group was created there, which presented the prototype of the Odra 1001 (Odra is a river over which Wrocław is located). For the first time in Poland, floating-point operations were implemented in hardware, although they didn't perform reliably enough.

Their next attempt, the Odra 1003, was reasonably efficient and suitable for serial production, which started in 1964. It was also much smaller than the previous iterations (as it can be seen on Fig. 10). After that, another successful version, the Odra 1013, was developed, which was two times faster than the previous one (a hundred of these were produced in Elwro). There was also one more after this - the Odra 1103 [12].

The next big leap in quality was with the Odra 1204 project. It was already equipped with an operating system, but still, despite the complete Algol translator, with rather modest software. Without a rich set of programs, one could not take full advantage of the potential of even the most capable computer. 


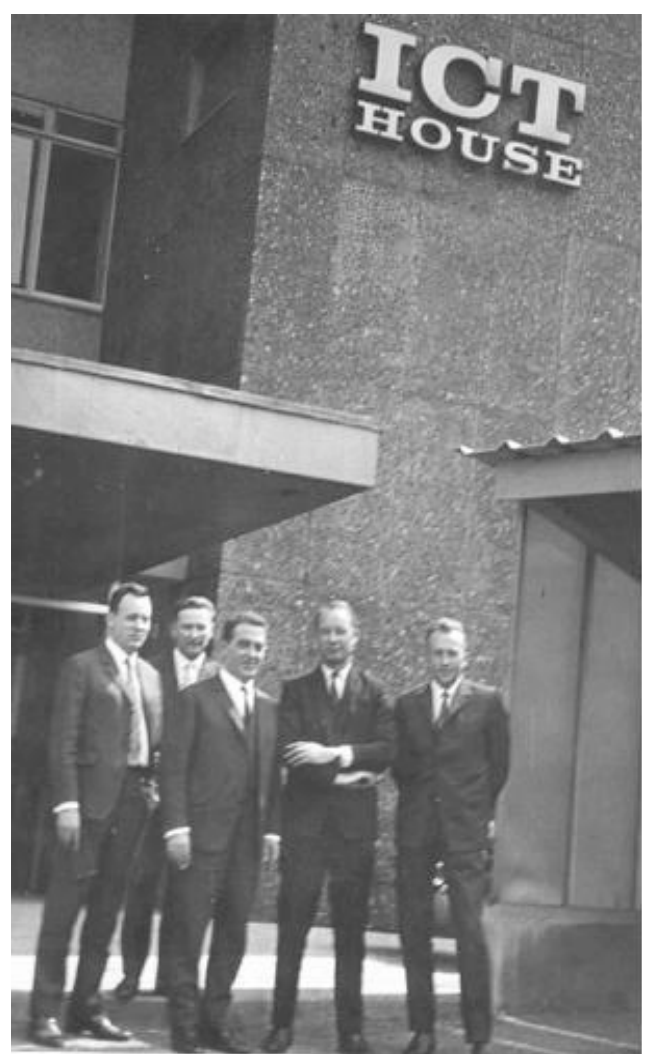

Fig. 11. Polish delegation in front of the ICT headquarters [13].

In order to create necessary software, Elwro would have to organize a large group of expert programmers and provide them with the necessary time. Instead, the plan was made to use the software of one of the reputable foreign companies and avoid this problem. That is, instead of creating software for an existing machine, build a computer on which existing software would work properly.

First, they had to find a company that would agree to such a deal. IBM, the strongest player in the global market at that time, was not interested. However, others were more willing to consider the offer, as long as their equipment was purchased as part of the package. Ultimately, the British firm ICT (International Computers and Tabulators), which soon became part of ICL (International Computers Limited), was selected.

ICT machines in Poland had already been in use for some time and several programmers and engineers were quite accustomed to them. It was decided that Poland would buy two large ICL 1900 computer. In return, Elwro would receive their documentation and software. In Figure 11, the "men in black" are shown in front of the ICT headquarters, having just signed the agreement in July 1967. This contract, as well as the government instructions for the Polish delegation, were published in [13].

The same team that made the Odra 1204 was assigned to this project, and as a result, many of the solutions they used were simply adopted from their experiences with the 
previous machine. Their task this time was more difficult, because the goal was to achieve a system that was fully compliant with the provided British hardware.

Despite the challenge, the team was ultimately successful. The first prototype of the Odra 1304, produced in early 1970, behaved exactly the same way as the ICL 1904, supporting all the same features: the George operating system (then regarded as one of the best in the world), several programming languages (including Algol, Fortran and Cobol, the most widespread at the time) and a library of over a thousand ready-to-use programs. An extensive set of external devices also functioned as expected.

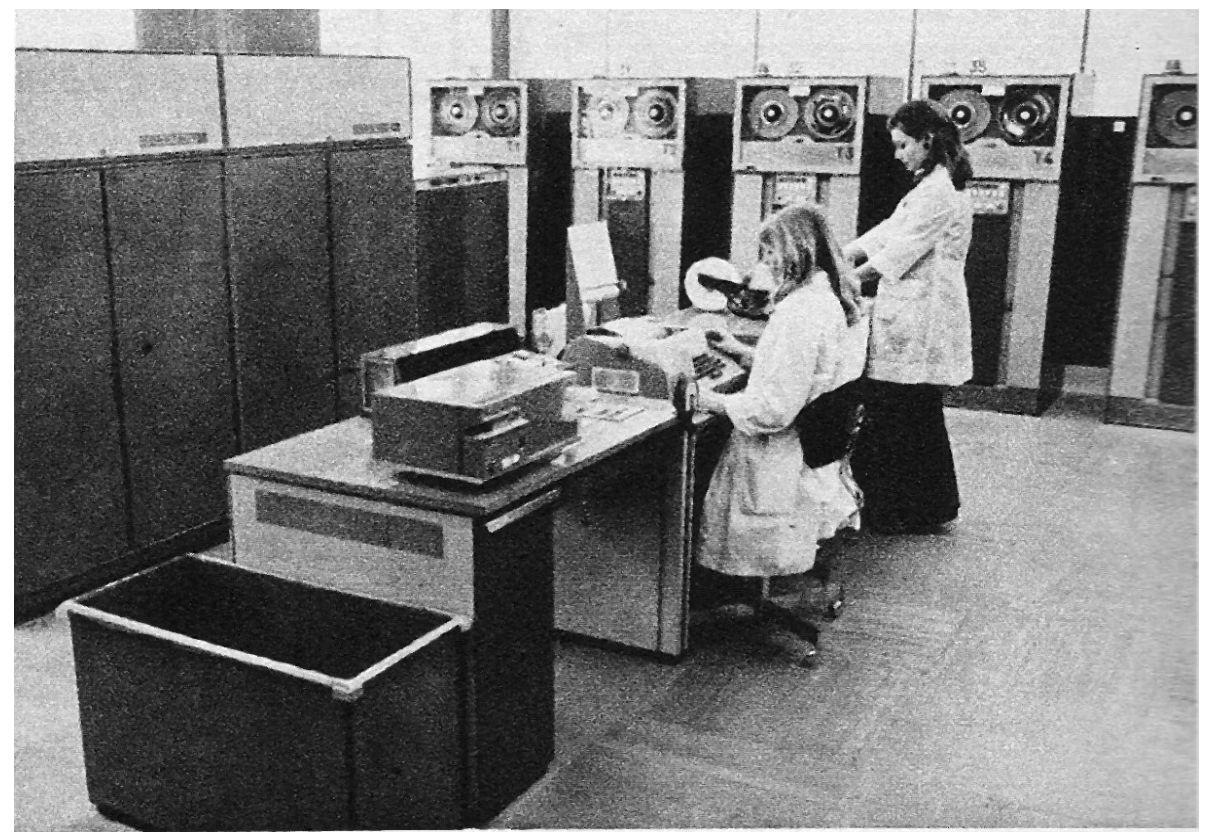

Fig. 12. ODRA 1304. Source: Polish Wikipedia

Odra 1304 and its successors, Odra 1305 and Odra 1325, had already started being built on an integrated circuit and were considered the best machines in the Eastern Bloc at the beginning of the seventies. With rich software and a full range of external devices, they became the perfect tools for computerization of many enterprises and institutions. In total, 587 units of the Odra 1300 series were produced. Through their lifetime, they enabled the computerization of entire industries such as construction and railway, in addition to various institutions and universities. Top-secret military applications, which were classified for many years, were later revealed to also disclose other use these devices. In 1999, an anti-aircraft system using a (then 20-year-old) Odra 1325 detected and shot down a presumably radar-invisible F-117 during its military mission in Serbia.

Elwro's strategy brought the desired results, but their success has been controversial, even to this day. Many questioned if it was worth copying other work, even if the source material was deemed the best available. Some insist that even when operating at a strict 
disadvantage, it is best to further develop original ideas, for the sake of scientific discovery and exploration. While clearly the agreement with ICT enabled the massive leap in overcoming complicated technological issues, others still suggest that solving them independently would have been fruitful in the long run.

\section{RYAD}

This dilemma - the choice between replicating proven solutions and own creation later appeared again on a much larger scale. In January 1967, a committee in the Academy of Sciences of the USSR decided that the efforts of Comecon countries should be consolidated and that all countries should join forces to create a unified system of computers. It was decided to follow the model of the IBM 360, the most widespread machines in the world at that time.

Once this decision was made, it became difficult to do anything else. If a country insisted on following their own designs, they were accepting the possibility of political consequences and economic marginalization. It was therefore recognized by the Polish government that participation in this unified program was in the best interest of the country. This undertaking was officially dubbed the Unified System of Electronic Computers, or RYAD.

In later years, the widely accepted theory for this period is that the Soviets forced Polish authorities into the RYAD project, in the same way Polish industries were forced to sell coal and ships at favorable prices. This would not have been an obvious supposition, because according to some officials, there did not seem to be too interest in about Poland's participation in the program, largely as a result of the contention from the ICL contract.

The distribution of tasks showed the Soviet disregard for Polish participation even more clearly. A medium size machine called the R-30 (EC 1030) was to be designed by the Yerevan institute and built in a factory in Kazan. The IMM was tasked with designing its own version of such a machine. Poland as a whole was also involved in this undertaking, although marginally, as they were only tasked with the production of printers, tape memories and terminals.

Prior to this effort, the IMM had been working on the ZAM machines, and in particular the ZAM-3 and ZAM-21 (launched in 1965). The last of this series, the ZAM-41, was not far from the contemporary notion of a computer. It performed 30,000 fixedpoint operations per second, was equipped with a tape memory, line printer, and other peripherals. Its production started in 1966. Once IMM became involved in R-30, it was forced to drop the ZAM line. 


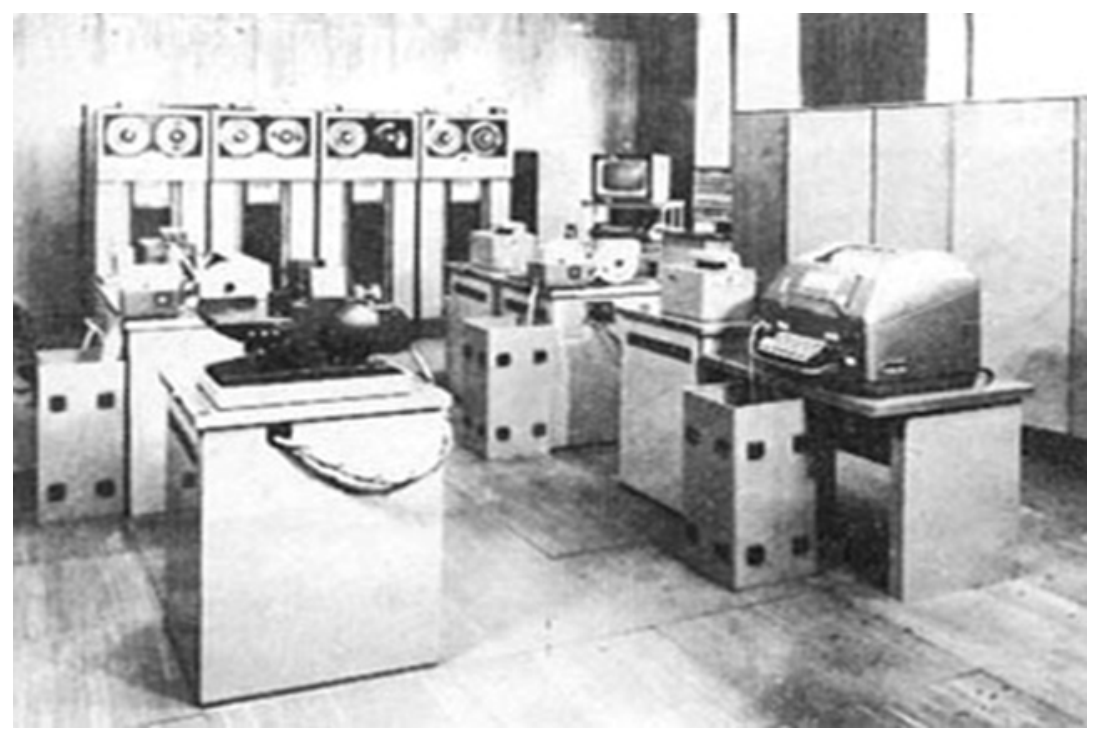

Fig. 13. ZAM-41. Source: Archives of the Institute of Mathematical Machines with permission of the Institute's director.

The IMM teams traveled back and forth to their counterpart institute in Yerevan, returning with cheaply bought Ararat cognac for their friends. In Warsaw, however, their task was met without much enthusiasm something which had been forced on them. This lack of enthusiasm ultimately led to the initiative being taken over from the IMM by the more dynamic Elwro.

As it turned out, Wrocław did quite well. The version of the R-30 built by the Polish team was smaller (it was located in just one cabinet while the Soviet one occupied three), did not need as much energy, and was more reliable. Yerevan's R-30 could not be launched at the Poznań International Fair in 1972, and the machine which did not work had to be presented.

Above all, the Polish version of the R-30 was significantly faster. At the Brno fair, all the RYAD devices were compared using a test prepared by the Czechoslovak Academy of Sciences, which measured the time it took to calculate a set of one million basic arithmetic operations. The R-20, developed in Bulgaria and Minsk, dealt with this test in 200 seconds. The R-30 from Yerevan needed 70 seconds, and the Elwro computer only 7 seconds. Another surprising result was the German R-40 machine, which was five times bigger, and ran the test in 9 seconds. [14].

Despite initial allegations of violation of the design rules established for the entire Unified System, the Polish computer received a separate R-32 number and in 1973 and decision was made to manufacture it. Even so, the Russians never bought a single piece. Instead, the Kazan factory which had produced the Yerevan R-30 began to implement the solutions used in R-32 in their own modernized R-33.

The development of the Unified System was continued in the 80 s by following the more advanced IBM 370 family. As part of this program called RYAD 2 Elwro manufactured R-34 computers until 1987. 


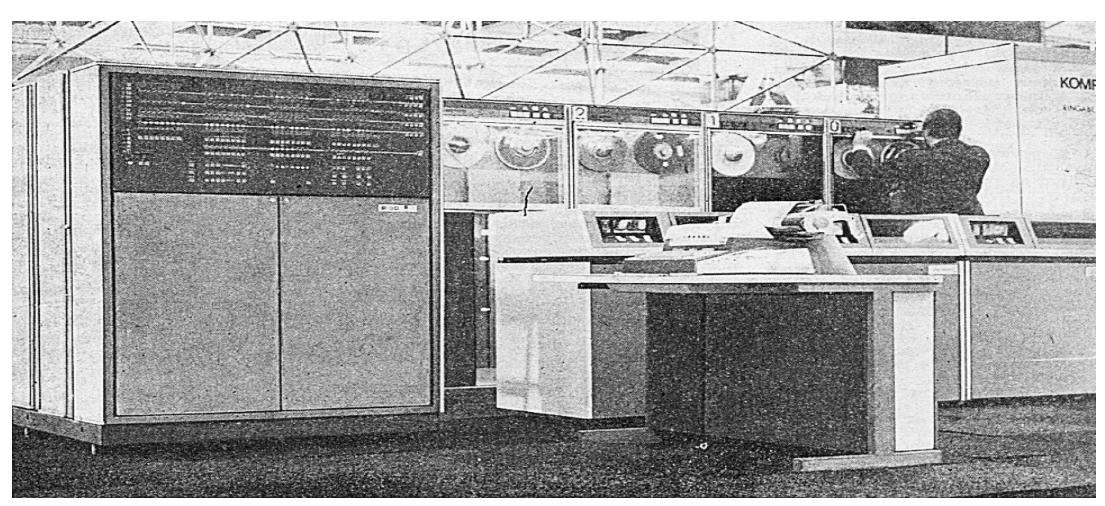

Fig. 14. R-32. Source: Polish Wikipedia

\section{Conclusions}

As mentioned at beginning, this paper is an extremely compressed English-language version of the material prepared for celebrations of the 70th birthday of Polish informatics in 2018. The Polish report was aimed at presenting the most complete description of the achievements in the years 1949-73 by organizing known facts and supplementing them with first-hand accounts and a large selection of archived materials. Like many such comprehensive reviews, it inevitably still has some gaps. However, after considerable discussion of this material at PIPS meetings and feedback from all Society members, there is hopefully not too much missing.

The Polish-language study, however extensive, still doesn't address some important issues of described period. Firstly, it does not mention the important discussion about what the ultimate purpose of computer would be. This debate first began in the late sixties, and ultimately concluded in a clear shift from the use of computers for strictly scientific use to their use for new applications in business and administration. The study also does not discuss potential benefits or losses as a result of technology transfer, the degree of Soviet influence in Poland or even the evident camaraderie between scientists from different counties despite ideological barriers.

Unfortunately, none of the PIPS members are historians by trade. Therefore, we don't feel qualified to discuss the broader historical and political context of this period - something which certainly merits more discussion. This paper is only a preliminary attempt to gather relevant facts and present them in a way allowing experts with a proper methodology of historical documentation, who may further organize and analyze them. One collection of such source materials is also readily available. Four years ago, PIPS invited its members to submit their memories, which resulted in a book, from which three essays have been cited here $[12,13,14]$.

\section{References}

1. Łukaszewicz, L.: On the Beginning of Computer Development in Poland. Annals of the History of Computing 12, 103-107 (1980). 
2. Marczyński, R.: The first Seven Years of Polish Digital Computers. Annals of the History of Computing 2, 37-48 (1980).

3. Madey, J., Sysło, M.: Początki informatyki w Polsce [The beginnings of computer science in Poland]. Informatyka 9,10 (2000).

4. Targowski, A.: Informatyka. Modele rozwoju i systemów [Informatics. Models of development and systems]. PWE (1980).

5. Łukaszewicz, L.: O poczatkach informatyki w Polsce [On the beginnings of computer science in Poland]. Materiały konferencji PTI "40 lat informatyki w Polsce" [Proceedings of the PIPS conference "40 years of computer science in Poland"] (1988).

6. Nowakowski, W.: 50 lat polskich komputerów, historia romantyczna. Esej historyczny [50 years of Polish computers, romantic history. Historical essay]. IMM (2008).

7. Miś, B.: To już pół wieku [It's been half a century]. Studio Opinii (2009).

8. Jasicki, Z., Kordylewski, J., Kudelski, G.: Zastosowanie maszyny matematycznej PARK do obliczania stopnia kompensacji mocy biernej w sieciach elektroenergetycznych [The use of the PARK mathematical machine to calculate the degree of reactive power compensation in power grids]. Applicationes Mathematicae 6 (1962).

9. Hołyński, M.: Raport w sprawie ANOPS-a [Report on ANOPS]. Polityka 5 (1977).

10. Bilski, E.: Wrocławskie Zakłady Elektroniczne ELWRO [Wroclaw Electronic Factory ELWRO]. https://aresluna.org/attached/computerhistory/articles/odra (2013)), last accessed 2018/11/02

11. Maćkowiak, B., Myszkier, A., Safader, B.: Polskie komputery rodziły się w ELWRO [Polish computers were born in ELWRO]. Archiwum Państwowe we Wrocławiu [Wroclaw State Archives] (2018).

12. Lesiński, J., Kociatkiewicz, P.: Komputer Odra 1103 [Computer Odra 1103]. In: Noga, M., Nowak, J. S. (eds.) Polska informatyka: wizje i trudne początki [Polish computer science: visions and difficult beginnings], pp. 277-280, PTI (2017).

13. Bilski, E., Kamburelis,T., Piwowar, B.: Wrocławskie Zakłady Elektroniczne. Okres komputerów Odra 1300 [Wroclaw Electronic Factory. Period of computers Odra 1300]. In: Noga, M., Nowak, J. S. (eds.) Polska informatyka: wizje i trudne początki [Polish computer science: visions and difficult beginnings], pp. 13-35, PTI (2017).

14. Kulisiewicz, T.: Własne konstrukcje, licencje, klony [Own constructions, licenses, clones]. In: Noga, M., Nowak, J. S. (eds.) Polska informatyka: wizje i trudne początki [Polish computer science: visions and difficult beginnings], pp. 57-94, PTI (2017).

15. Hołyński, M.: 70-lecie polskiej informatyki [70th anniversary of Polish computer science], http://biuletyn.pti.org.pl/BiuletynPTI_2016-04.pdf (2016), last accessed 2018/11/02.

16. Hołyński, M.: Analog czy cyfra? [Analog or digital?], http://biuletyn.pti.org.pl/BiuletynPTI_2017-01.pdf (2017), last accessed 2018/11/02.

17. Hołyński, M.: Pierwszy polski komputer [First Polish computer], http://www.biuletyn.pti.org.pl/BiuletynPTI_2017-02.pdf (2017), last accessed 2018/11/02.

18. Hołyński, M.: Mamy ZAM-y [We have ZAMs], http://biuletyn.pti.org.pl/BiuletynPTI_2017-03-04_ewydanie.pdf (2017), last accessed 2018/11/02.

19. Hołyński, M.: Wczesne lata 60-te: wysyp maszyn [Early 1960s: abundance of machines], http://www.biuletyn.pti.org.pl/BiuletynPTI_2018-01_ewydanie.pdf (2018), last accessed 2018/11/02.

20. Hołyński, M.: Naśladować innych, czy rozwijać własne pomysły? [Imitate others or develop your own ideas?], http://www.biuletyn.pti.org.pl/BiuletynPTI_2018-02_ewydanie.pdf (2018), last accessed 2018/11/02. 